\title{
Biochemical and Morphological Studies of Rat Submandibular Gland: II. Partial Purification of Proteins from Granule-Rich Fraction
}

\author{
S. G. CHAKRABARTI, C. T. HANKS,* and S. P. JOHNSON
}

Institute of Dental Research, Departments of Oral Pathology and Oral Biology, School of Dentistry, University of Michigan, Ann Arbor, Michigan 48104, USA

Soluble proteins derived from a centrifuged and filtered granule-rich fraction of homogenized rat submandibular gland were analyzed by gel filtration, ion-exchange chromatography, and polyacrylamide gel electrophoresis. Both the granule-rich fraction and final supernatant fraction contained alkaline esterase activity. The major protein component, derived from granules of the convoluted tubules, was further resolved into a series of peptides ranging in molecular weight from 9,000 to 55,000 daltons.

A number of preparations with soluble trypsinlike enzymes have been derived from homogenates of rat and mouse submandibular glands (SMGs).1-13 For the most part, however, these studies did not deal with the distribution of these enzymes within the subcellular compartments. Therefore, it was difficult to determine whether the enzymes were synthesized for use within the cell or rather for a secretory function.

In rat SMGs, both renin and kallekrein activities appear to be associated with alkaline esteropeptidase-rich granule preparations, whereas in similar preparations from mouse SMGs, elevated levels of nerve growth factor (NGF) and epidermal growth factor (EGF) have been demonstrated in addition to renin and kallekrein activities. ${ }^{14-17}$ In a previous article, our laboratory reported the distribution of alkaline esteropeptidase

This investigation was supported, in part, by $\mathrm{Na}$ tional Institutes of Heałth Research Grants No. DE0?731 and DE03389 from the National Institute of Dental Research, Bethesda, Md.

Received for publication October 7, 1974.

Accepted for publication March 4, 1975 .

- Present address: Division of Dermatology, Howard University Medical College, Washington, DC.

Reprint requests to $C$. $T$. Hanks.
(AEP) activity in all centrifugal fractions of rat SMGs and the isolation of a fraction rich in granules resembling those of the convoluted tubules of this gland. 18 The present article reports details of isolation, partial purification, and immunohistochemical localization of enzymes from the cytosol and granule-rich fractions.

\section{Materials and Methods}

Adult male Sprague-Dawley rats weighing 400 to $500 \mathrm{gm}$ each were maintained in our animal care facilities before they were killed. Pairs of submandibular glands were excised from each of six rats, cleaned, and fractionated by differential centrifugation. The crude, granule-rich fraction $\left(\mathrm{P}_{2}\right)$ and the final supernatant fraction $\left(S_{4}\right)$ were purified as previously described.18 The $P_{2}$ fraction was then washed with the same buffer several times and filtered through nuclepore filters ${ }^{a}$ to obtain the washed and filtered granule-rich fraction $\left(\mathrm{wfP}_{2}\right)$. Smears prepared from the resuspended $\mathrm{wfP}_{2}$ fraction were stained with toluidine blue and examined routinely under the light microscope for quick estimation of the purity of the $\mathrm{P}_{2}$ preparation. Satisfactory preparations were examined by light and electron microscopy by routine methods. The $\mathrm{wfP}_{2}$ fraction obtained in this manner constituted starting material for the isolation and purification of proteins reported in this article.

ASSAY METHOD FOR ESTEROPEPTIDASES.-For measuring the esterase activity, $0.5 \mathrm{mM} \alpha-N$. benzoyl-L-arginine ethyl ester (BAEE) b was used as a substrate in a $0.1 \mathrm{M}$ glycine- $\mathrm{NaOH}$ buffer at a $\mathrm{pH}$ of 9.2 or a $0.1 \mathrm{M}$ Tris-HCl

Arthur H. Thomas Co., Philadelphia, Pa.

b Sigma Chemical Co., St. Louis, Mo. 
buffer at a $\mathrm{pH}$ of 8.0. The esterase activity was followed by measuring the rate of change of absorbance (with time) at a 253$\mathrm{nm}$ wavelength with use of a double-beam recording spectrophotometer ${ }^{18}$ Total activity was expressed as the number of $\mu$ moles of benzoyl-arginine produced per minute per fraction. Protein concentrations were measured according to the method of Lowry et al, $^{19}$ using bovine serum albumin as the standard.

Chromatographic purifications,-The wfP $_{2}$ fraction was suspended in a $0.01 \mathrm{M}$ Tris-HCl buffer at a $\mathrm{pH}$ of 7.4 and subjected to rapid freeze-thaw seven times. The suspension was then centrifuged at $11,000 \times \mathrm{g}$ for 15 minutes at $4 \mathrm{C}$. The supernatant fraction was subsequently dialyzed against a $0.01 M$ Tris-HCl buffer ( $\mathrm{pH}, 7.4)$ and then was lyophilized. The sample was then reconstituted in a $0.01 \mathrm{M}$ Tris- $\mathrm{HCl}$ buffer $(\mathrm{pH}, 7.4)$ and subjected to gel filtration and ion exchange chromatography. In addition, the $\mathrm{S}_{4}$ fraction was dialyzed against a $0.01 \mathrm{M}$ Tris-HCl buffer ( $\mathrm{pH}, 7.4)$, lyophilized, reconstituted in the same buffer, and also fractionated by gel filtration and ion-exchange chromatography at $4 \mathrm{C}$.

For gel filtration, beads of Sephadex G$100^{\mathrm{d}}$ were allowed to swell in a $0.01 \mathrm{M}$ Tris$\mathrm{HCl}$ buffer $(\mathrm{pH}, 7.4)$ for three days in the cold without heating or stirring. A slurry of swollen beads was packed into a $2.5 \times 100$ $\mathrm{cm}$ column to the $83-\mathrm{cm}$ level. The void volume of this column was $110 \mathrm{ml}$ as determined by the complete elution of Blue Dextran 2000. The gel beads were washed by passing several volumes of buffer through the gel bed (bed volume of $402.5 \mathrm{ml}$ ). The protein preparation from either the wfP $_{2}$ fraction or the $S_{4}$ fraction was then placed on the column and eluted with the same buffer. The column eluate was monitored for absorbance at $280 \mathrm{~nm}$.

For ion-exchange chromatography, $3 \mathrm{gm}$ of DEAE cellulose powder (exchange capacity $0.9 \mathrm{mEq} / \mathrm{gm}$ ) were suspended in a $0.01 \mathrm{M}$ Tris-HCl buffer ( $\mathrm{pH}, 7.4$ ) and poured into a $1.5 \times 30-\mathrm{cm}$ column. Fractions eluted from the Sephadex G-100 column, and rich in esterase activity, were combined and adsorbed on DEAE cellulose by passing them through the column. The proteins were

\footnotetext{
e Spectronic 505, Bausch and Lomb, Rochester, NY.

d Pharmacia Fine Chemicals, Uppsala, Swed.
}

eluted by a linear gradient of $0.1 M$ to $1.0 \mathrm{M}$ $\mathrm{NaCl}$ in a $0.01 \mathrm{M}$ Tris- $\mathrm{HCl}$ buffer at a $\mathrm{pH}$ of 7.4. The elution pattern was monitored as described, and 10-ml fractions were collected.

Polyacrylamide Gel electrophoresis.Electrophoresis of four protein fractions from the DEAE cellulose column was performed in the presence and absence of $0.1 \%$ sodium dodecyl sulfate (SDS) ${ }^{e}$ and $0.1 \%$ $\beta$-mercaptoethanol.f A $10 \%$ acrylamide gel solution was made by combining $9 \mathrm{ml}$ of acrylamide monomer solution (22 gm acrylamides and $0.3 \mathrm{gm} \mathrm{BISg}$ in $100 \mathrm{ml}$ distilled water) with $10 \mathrm{ml}$ of a $0.05 \quad M$ sodium borate buffer $(\mathrm{pH}, 9.2), 25 \mu \mathrm{l}$ TEMED, $\mathrm{g}$ and $1.01 \mathrm{ml} 0.9 \%$ ammonium persulfate. The protein-rich column fractions, as well as dog serum controls, which had been dialyzed against either a $0.05 M \mathrm{Na}$ borate buffer or SDS- $\beta$-mercaptoethanol and then concentrated by ultrafiltration to $\mathbf{5 0}$ to $\mathbf{1 0 0}$ $\mu \mathrm{g}$ protein $/ 0.2 \mathrm{ml}$, were placed on top of the polymerized gels. The gels were run at 1.5 ma per gel for 30 minutes in a $0.05 M$ sodium borate electrode buffer $(\mathrm{pH}, 9.2)$, and then at 3 ma per gel for three hours or until the tracing dye (bromophenol blue) $f$ neared the end of the gel. The gels were then stained with a $0.05 \%$ solution of Coomassie Brilliant blue ${ }^{\mathrm{h}}$ in $7 \%$ aqueous acetic acid or with the periodic acid-Schiff (PAS) method. ${ }^{20}$ The gels were destained by dialysis against $7 \%$ aqueous acetic acid and scanned at $650 \mathrm{~nm}$ on a recording spectrophotometer.i

IMmuNologic studies.-Antigen was prepared by dialyzing the postmicrosomal supernatant against a $0.01 M$ Tris- $\mathrm{HCl}$ buffer $(\mathrm{pH}, 7.4)$. Dialyzed material was lyophilized and reconstituted in a $0.01 M$ Tris- $\mathrm{HCl}$ buffer $(\mathrm{pH}, 7.4)$. This material was then passed over a Sephadex G-100 column and fractions with esterase activity were pooled. The pooled fractions were concentrated by lyophilization and reconstituted again in a $0.01 M$ Tris-HCl buffer $(\mathrm{pH}, 7.4)$. An antibody preparation, in turn, was obtained by repeated subcutaneous injections of 0.25

\footnotetext{
e Fisher Scientific Co., Fairlawn, NJ.

Matheson Coleman and Bell, Norwood, Ohio.

g Acrylamide, $N, N^{\prime}$-methylenebisacrylamide (BIS) and $N, N, N^{\prime}, N^{\prime}$-tetramethylethylenediamine (TEMED), Eastman Kodak Co., Rochester, NY.

h Colab Laboratories, Inc., Glenwood, Ill.

1 Gilford 2400, Gilford Instrument Laboratories, Inc., oberlin, Ohio.
} 
$\mathrm{ml}$ (1.1 $\mathrm{mg}$ protein) of the antigen preparation into the scapular region in New Zealand rabbits. The first antigen injection was accompanied by $0.5 \mathrm{ml}$ of Freund's complete adjuvant. $j$ Succeeding weekly antigenic injections of the same amount were accompanied by $0.5 \mathrm{ml}$ of Freund's incomplete adjuvant. After five injections, the rabbits were bled from an ear vein, serum was separated from cells, and the $\gamma$-globulin fraction was purified by repeated ammonium sulfate precipitation.21 This $\gamma$-globulin fraction was used to study immuno-double diffusion of the soluble protein antigens obtained from DEAE cellulose chromatography of the $\operatorname{wfP}_{2}$ centrifugal preparation against purified antibody.

For the immunohistochemical procedures, $\gamma$-globulin precipitated by ammonium sulfate from rabbit serum was dialyzed against phosphate buffered saline (PBS).21 The dialyzed material was absorbed with DEAE cellulose to remove non- $\gamma$ globulin contaminants, dialyzed against borate buffered saline, ${ }^{22}$ and lyophilized. For conjugation of peroxidase to antirabbit $\gamma$ globulin, $50 \mathrm{mg}$ of horseradish peroxidase was added to $50 \mathrm{mg}$ of purified commercial goat antirabbit serum ${ }^{1}$ in $2 \mathrm{ml}$ of a $0.5 \mathrm{M}$ sodium carbonate buffer, with a $\mathrm{pH}$ of 10.2 . Conjugation was brought about by the addition of $0.75 \mathrm{ml}$ of $0.5 \% \quad p, p^{\prime}$-difluoro- $m, m^{\prime}$ dinitrophenylsulfone (FNPS) ${ }^{m}$ The mixture was stirred for four hours at $4 \mathrm{C} .{ }^{23}$ Then, the mixture was dialyzed against PBS for two days. Conjungated $\gamma$-globulin was then separated from peroxidase by precipitation with ammonium sulfate at $50 \%$ saturation. Precipitated $\gamma$-globulin was removed by centrifugation at $5,000 \times \mathrm{g}$ for ten minutes in the cold. The precipitate was dissolved in the original volume of PBS and the precipitation procedure repeated twice more. Portions of the conjugated antiserum were treated with liver powder just before use to remove nonspecific antibody.

Slices of adult male rat SMG, with sublingual gland intact underneath the capsule, were fixed eight hours in $2 \%$ paraformaldehyde with picric acid in $0.05 M$ sodium

1 Difco Laboratories, Detroit, Mich.

r Sigma Chemical Co., St. Louis, Mo.

1 Hyland Division of Travenol Laboratories, Inc., Costa Mesa, Calif.

m General Biochemicals Division, North American Mogul Products Co.; Chagrin Falls, Ohio. phosphate buffer, 24 and then washed overnight in PBS. After dehydration in ethanol, the tissue was embedded in $100 \%$ polyethylene glycol, sectioned at 10 micrometers, and placed on glass slides.25 Slides were wetted with PBS for five minutes and reacted with purified antibody for 15 minutes at $37 \mathrm{C}$. Slides were then washed three times with PBS. A drop of peroxidase-labeled antirabbit $\gamma$-globulin was placed on tissue sections and reacted for 15 minutes at $37 \mathrm{C}$ and washed three times with PBS. Finally, the tissue was reacted with saturated subs-

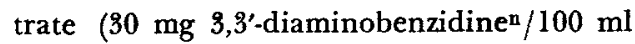
in $0.05 M$ Tris-HCl buffer, with a $\mathrm{pH}$ of 7.6) containing $0.005 \% \mathrm{H}_{2} \mathrm{O}_{2}$ for ten minutes at $37 \mathrm{C}$. After the tissue had been washed with PBS several more times, cover slips were mounted over the tissue with 9:1 PBSglycerol solution. ${ }^{25}$

\section{Results}

Table 1 shows the distribution of esterase activity in centrifugal fractions. In this study, the $\mathrm{P}_{2}$ contained approximately $40 \%$, and the $\mathrm{S}_{4}$ approximately $60 \%$ of the total activity of the starting homogenized glandular material. After the $\mathrm{P}_{2}$ had been washed and filtered through a series of nuclepore filters, $26 \%$ of the total activity (that is, 7,160 $\mu$ moles BAEE hydrolyzed/fraction/minute) remained in the $\mathrm{wfP}_{2}$ fraction. The granule content of the pellet was estimated at 70 to $80 \%$ of the total number of particles in the wf $P_{2}$ preparation.

CHROMATOGRAPHY AND ELECTROPHORESIS OF $\mathrm{P}_{2}$ Fraction.-Eighty percent of the resuspended $\mathrm{wfP}_{2}$ fraction $(5,728 \mu$ moles BAEE hydrolyzed $/ \mathrm{min}$ ) was prepared for gel filtration as described. The soluble material placed on the column had a total activity of 3,122 $\mu$ moles BAEE hydrolyzed $/ \mathrm{min}$. Therefore, approximately $45 \%$ of the activity was lost in the process. After freeze-thawing the centrifugal pellet contained a few incompletely "dissolved" granules, which accounts for some of this loss. The reconstituted sample was then eluted from the Sephadex G-100 column in four peaks (Fig 1). Approximately $96 \%$ of the total BAEE placed on the column was eluted in fractions 12 to 21. Maximum specific activity was associated with fraction 17 (Table 2). The void column (first 11 fractions) contained $7.1 \%$ of the

n Sigma Chemical Co., St. Louis, Mo. 
TABLE 1

Distribution of Alkaline Esterase activity in Centrifugal fractions

\begin{tabular}{lcccc}
\hline \hline & $\begin{array}{c}\text { Total BAEE } \\
\text { Activity* } \\
\text { ( } \mu \text { moles } \\
\text { BA formed/ } \\
\text { fraction) }\end{array}$ & $\begin{array}{c}\text { \% of } \\
\text { Total } \\
\text { Activity }\end{array}$ & $\begin{array}{c}\text { Total } \\
\text { Protein } \\
\text { (mg/ } \\
\text { fraction) }\end{array}$ & $\begin{array}{c}\text { Specific } \\
\text { Activity* } \\
\text { ( } \mu \text { moles BA } \\
\text { formed/mg } \\
\text { protein) }\end{array}$ \\
\hline Homogenate & 27,430 & 100 & 435 & 63 \\
Nuclear Pellet & 1,930 & 7 & 53.3 & 36 \\
$\mathbf{P}_{2}$ & 11,100 & 40 & 95.7 & 116 \\
$\mathbf{P}_{3}$ & 360 & 1.3 & 30.5 & 11.8 \\
$\mathbf{P}_{4}$ & 675 & 2.5 & 25.5 & 26.5 \\
$\mathbf{S}_{4}$ \% Recovery & 17,000 & 62 & 118 & 144 \\
\% & & $113 \%$ & $70 \%$ & \\
\hline
\end{tabular}

Note: $P_{2}$, granule-rich fraction; $P_{3}$, mitochondria-rich fraction; $P_{4}$, microsome-rich pellet; $S_{4}$, final supernatant.

- $\mu$ moles $\alpha-N$-benzoyl-I arginine formed per minute at $25 \mathrm{C}(\mathrm{pH}, 9.2)$.

protein and $0.9 \%$ of the total esterase activity placed on the column.

Fractions 12 to 21 were then pooled and adsorbed onto the DEAE cellulose column. Gradient elution gave four major protein peaks (I, IV, V, and VI) with shoulders (II and III). Four column fractions (Fractions 22, 28, 31, and 33) with the highest specific activity (Table 2) were selected for further analysis.

Each of the four column fractions was subjected first to non-SDS polyacrylamide gel electrophoresis. The pattern of Coomassie Brilliant blue stained bands at $650 \mathrm{~nm}$ is shown in Figure 2. Fraction 22 (Fig 2,D) had two discrete bands, whereas fraction 28 (Fig 2,C) produced a major band of more negatively charged proteins than either of the bands in fraction 22. Fraction 31 (Fig
2,B) and fraction 33 (Fig 2,A) also produced two bands each. Both of these fractions may contain the same two major proteins. These gel profiles indicate that the selected fractions from the DEAE cellulose column contained at least five, incompletely separated, major proteins. In addition, since none of these bands was analyzed for BAEE hydrolysis, we were unable to determine which represented alkaline esterases. When duplicate gels were stained with PAS, the intensity of staining was faint for one band in fraction 22 and one band in fraction 33 . At the optimum protein concentration used for Coomassie Brilliant blue staining, no other bands were stained with PAS.

Table 3 lists the migration rates of proteins from the same four-column fractions after subjection to SDS-mercaptoethanol

TABLE 2

Partial Purification of Enzymes

\begin{tabular}{lcccc}
\hline \hline \multicolumn{1}{c}{ Fraction } & $\begin{array}{c}\% \text { of } \\
\text { Protein } \\
\text { Placed on } \\
\text { Column }\end{array}$ & $\begin{array}{c}\text { \% of } \\
\text { Protein } \\
\text { in Ho- } \\
\text { mogenate }\end{array}$ & $\begin{array}{c}\text { Specific } \\
\text { Activity* }\end{array}$ & $\begin{array}{c}\text { Purifi- } \\
\text { cation }\end{array}$ \\
\hline Homogenate & 100 & 100 & 61 & 1 \\
wfP & $\ldots$ & 14.1 & 116 & 1.9 \\
G-100 peak tube & 5 & 0.53 & 250 & 4.0 \\
DEAE Cellulose & & & & \\
$\quad$ (peak tubes only) & & & & \\
$\quad$ Fraction 22 & 4.7 & 0.16 & 170 & 2.8 \\
$\quad$ Fraction 28 & 7.5 & 0.26 & 240 & 3.9 \\
$\quad$ Fraction 31 & 9.9 & 0.33 & 535 & 8.8 \\
Fraction 33 & 15.9 & 0.53 & 347 & 5.7 \\
\hline
\end{tabular}

Note: $\mathrm{wfP}_{2}$, washed and filtered granule-rich fraction.

* $u$ moles $\alpha-N$-benzoyl-L-arginine formed per minute per milligram of protein at $4 \mathrm{C}$ (pH, 9.2). 


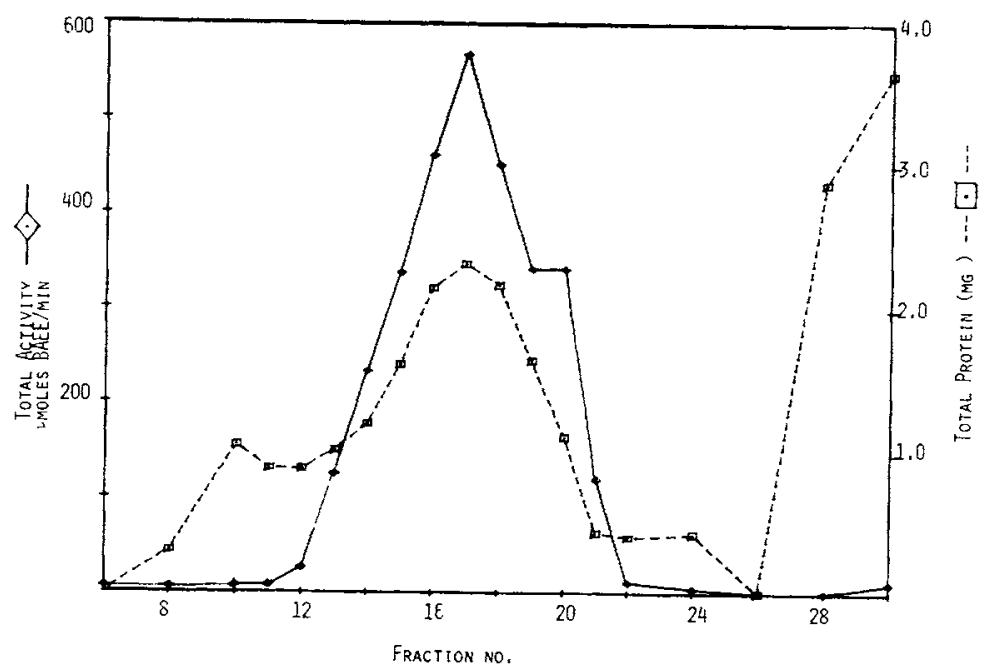

FIG 1.-Abscissa, fraction number (10 ml each) from Sephadex G-100 gel filtration of soluble proteins from $\mathrm{wPP}_{2}$ preparation; left ordinate, total enzyme act per fraction expressed in $\mu$ moles BAEE hydrolyzed per minute; right ordinate, total milligrams of protein per fraction. Broken line, protein; solid line, alkaline esteropeptidase activity.

treatment. Molecular weights of protein bands were determined using four proteins with known molecular weights as markers. Fraction 22 from the DEAE cellulose column yielded two peptides of approximately 12,000 and 6,500 daltons, respectively. SDS treatment of fraction 28 also produced two bands, of about 55,000 and 22,500 daltons molecular weight. Fraction 31 consisted of only one band with a molecular weight of approximately 35,000 , whereas fraction 33 had two bands of 35,000 and 12,000 daltons, respectively.
CHROMATOGRAPHY AND ELEGTROPHORESIS OF POSTMICROSOMAL SUPERNATANT.-Figure 3 shows the elution pattern obtained from gel filtration of the $S_{4}$ fraction on a Sephadex G-100 column. Five to six proteins were present in the resultant fractions. Three of these are shown in Figure 3. Esterase activity was always associated with protein in a shoulder of peak I (area II) and in peak III. Fractions 12 to 19 represented $99 \%$ of the total eluted esterase activity. Fractions 12 to 19 were chromatographed on DEAE cellulose and gave an elution of at least three discrete

TABLE 3

SDS-Gel Electrophoresis of Proteins Partially Purified from Granule-Rich Preparation of the Rat Submandibular Gland

\begin{tabular}{|c|c|c|}
\hline Material & $\begin{array}{c}\text { Migration } \\
(\mathrm{mm})\end{array}$ & $\begin{array}{l}\text { Approximate } \\
\text { Molecular } \\
\text { Weights }\end{array}$ \\
\hline \multicolumn{3}{|c|}{ DEAE cellulose column fractions } \\
\hline No. 22 & 44 and 54 & 12,000 and 6,500 \\
\hline No. 28 & 23 and 34 & 55,000 and 22,500 \\
\hline No. 31 & 28 & 35,000 \\
\hline No. 33 & 28 and 44 & 35,000 and 12,000 \\
\hline Human gamma II & 17 & 160,000 \\
\hline Bovine serum albumin & 20 & 68,000 \\
\hline Chymotrypsinogen & 31 & 25,700 \\
\hline Cytochrome C & 41 & 13,900 \\
\hline
\end{tabular}




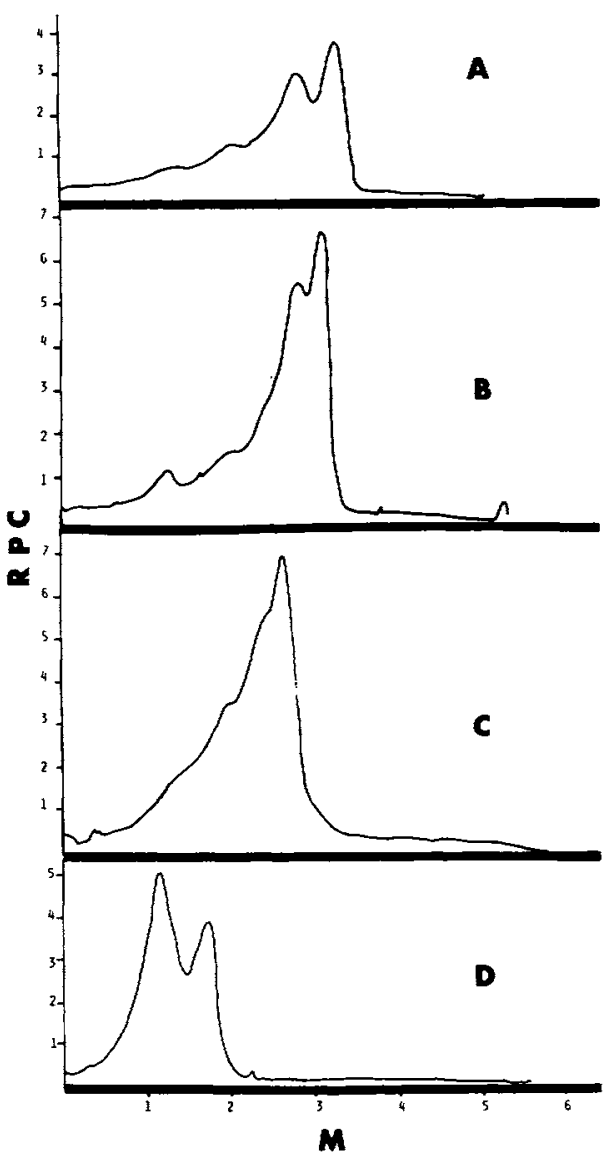

Fic 2.-Abscissa, relative mobility of soluble "granule" proteins (without SDS treatment) in $10 \%$ cross-linked polyacrylamide gels and stained with Coomassie Brilliant blue; ordinate, relative protein concentration when scanned for absorbance at $550 \mathrm{~nm}$. Profiles $A$ to $D$ are for four different fractions eluted from DEAE cellulose column (Fig 7 ): $A$, fraction 33 ; $B$, fraction 31 ; $C$, fraction $28 ; D$, fraction 22 . Positive pole and direction of movement of proteins is to right.

protein peaks (I, III, and VI) and three shoulders (areas II, IV, and V) (Fig 4). Esterase activity was associated with the protein peaks, I, III, and VI.

Fractions 20 and 30 from the DEAE cellulose column were also subjected to non-SDS polyacrylamide gel electrophoresis. Fraction 20 gave two discrete protein bands and several minor bands (Fig 5,B), whereas fraction 30 gave two partially separated major bands and one minor band (Fig 5,A). The minor band may be a contaminating protein from fraction 20. Furthermore, gels of fraction 30, but not of fraction 20, gave a strongly PASpositive band corresponding in position to the Coomassie Brilliant blue-staining band.

IMMUNODIFFUSION OF PURIFIED FRACTIONS.Figure 6 is a typical agar gel from the immuno-double diffusion studies. The central well contained purified undiluted antibody preparation. Wells 1 and 4 contained the original antigen $\left(\mathrm{S}_{4}\right)$ diluted $1: 32$, which was the optimal dilution as determined by immunodiffusion. Undiluted fractions 22, 28, 31 , and 33 from the DEAE cellulose column (Fig 7) were placed in wells $2,3,5$, and 6, respectively. A continuous double diffusion ring (series of arcs that converge at approximately $2.5 \mathrm{~mm}$ away from the edge of the central hole) was formed. Therefore, the $S_{4}$. fraction and the four DEAE cellulose column-purified fractions from wfP $_{2}$ appeared to contain a single cross-reactive antigen.

IMMUNOHISTOCHEMISTRY. - The peroxidase reaction site, indicating presence of antigenic protein, was limited to discrete units in the submandibular gland but not the sublingual gland. The ductal structures of the SMG were stained dark brown which was interpreted as a positive reaction. In contrast, acinar cells of the SMG as well as all of the sublingual gland structures gave a negative reaction. At a higher magnification of the SMG ductal structures, the granules in the convoluted portion of the ductal system showed the most intense reaction (Fig 8). The basal portions of these cells, containing nuclei, mitochondria, and plasma membranes were much lighter or unreactive.

\section{Discussion}

The specific assay conditions in this study were chosen in light of the findings of Riekkinen, Ekfors, and Hopsu-Havu, ${ }^{7}$ as well as our own data. 18 These data indicated that the major group of soluble proteins from rat SMG homogenate hydrolyzed both amide and ester substrates optimally at about a $\mathrm{pH}$ of 9.3, and hydrolyzed BAEE at a greater rate than other substrates. However, rather than purifying the hydrolytic enzymes by salt and acid precipitations of crude extracts as in previous studies, ${ }^{6,13,26}$ differential centrifugation was used to isolate various organelle-rich fractions from which proteins were solubilized. 18

It is obvious from comparison of the en- 


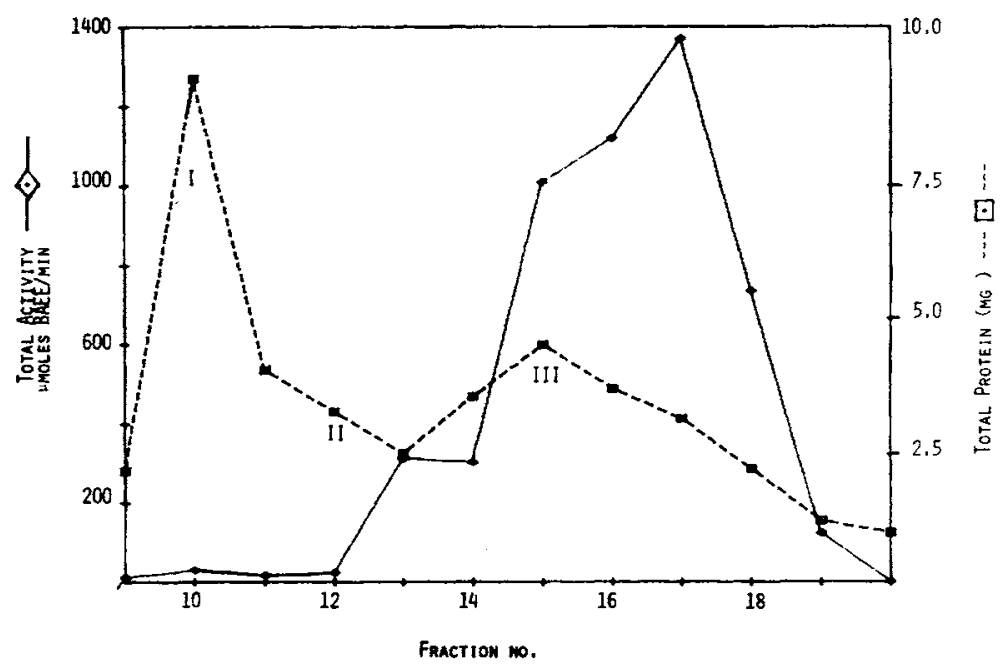

Fig 3-Abscissa, fraction number (10 ml each) from Sephadex G-100 gel filtration of final supernatant fraction; left ordinate, total enzyme act per fraction expressed in $\mu$ moles BAEE hydrolyzed per minute; right ordinate, total $\mathrm{mg}$ protein-fraction. Broken line, protein; solid line, alkaline esteropeptidase activity.

zyme activities of the starting material in our previous article ${ }^{18}$ to those of this report (Table 1 ), as well as the varying numbers of granules in different cells of the convoluted tubules, that there is diversity of enzymatic activity in rats of the same weight, age, and sex. With the limitations in the amount of starting material from six rats, we were able

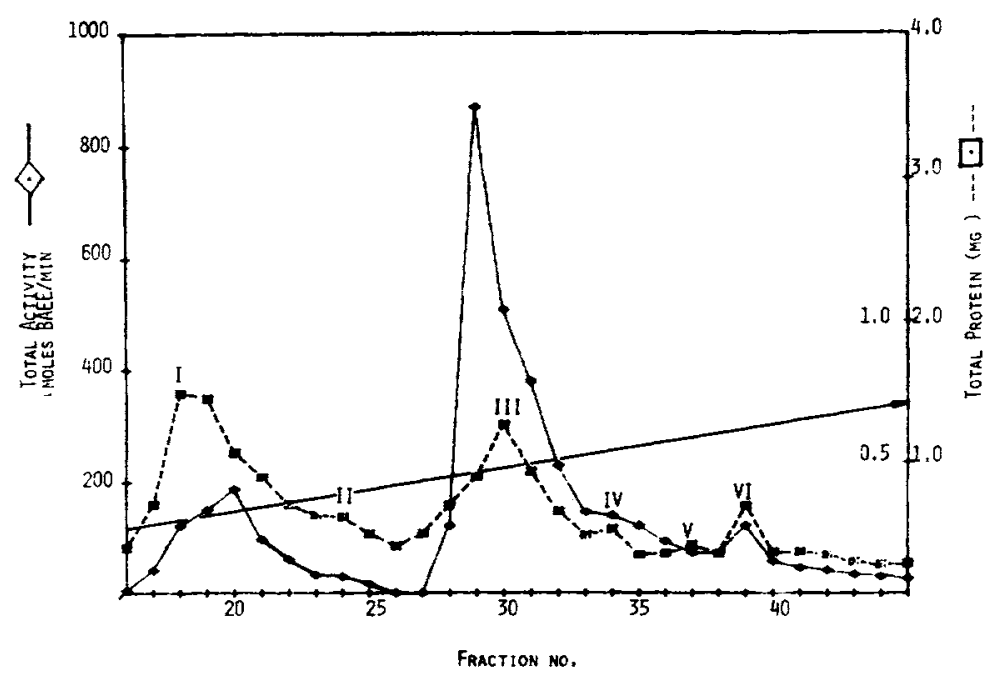

Fig 4.-Abscissa, column fraction number $(10 \mathrm{ml}$ each) from DEAE cellulose chromatography of pooled fractions 12 to 19 in Figure 3 ; left ordinate, total enzyme act-fraction expressed in $\mu$ moles BAEE hydrolyzed per minute; right outer ordinate, total milligrams of protein per fraction; right inner ordinate, molar concentration of $\mathrm{NaCl}$ eluting solution. Broken line, protein; solid line, alkaline esteropeptidase; arrow, NaCI elution gradient. 


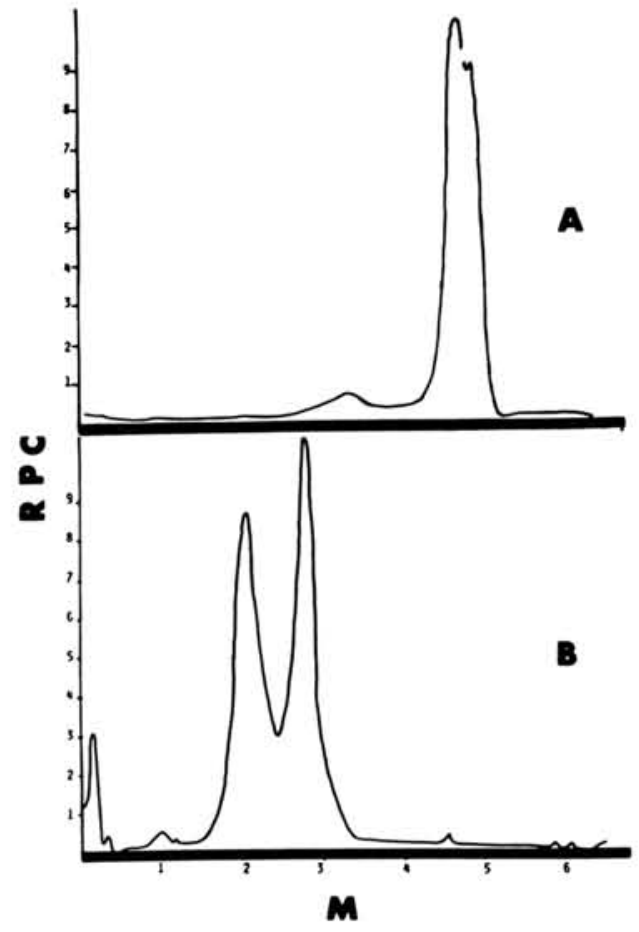

FIG 5.-Abscissa, relative mobility of "supernatant" proteins on polyacrylamide gels and stained with Coomassie Brilliant blue; ordinate, relative protein concentration when scanned at $550 \mathrm{~nm}$. Profiles A and B are for two different fractions eluted from DEAE cellulose column (Fig 4): $A$, fraction 30; $B$, fraction 20. Positive pole and direction of movement of proteins is to right.

to concentrate our enzyme preparation so that one fraction from the DEAE cellulose column had a specific esterase activity of 535 $\mu$ moles BAEE hydrolyzed $/ \mathrm{mg}$ protein $/ \mathrm{min}$. This is approximately a third of the specific activity reported for the purified rat SMG enzyme, salivain, 7 as well as the specific activity of purified mouse SMG protein "inducible" by testosterone injections. ${ }^{3}$ Apparently, there are a larger number of soluble trypsinlike proteases in crude gland extracts of mouse SMG than in a similar preparation of rat SMG. Ekfors and Hopsu$\mathrm{Havu}^{26}$ described six esteropeptidases from mouse SMG homogenates ranging in molecular weights from 25,000 to 30,000 and exhibiting optimum $\mathrm{pH}$ values of 8.0 to 10.5 . In contrast, the same group earlier reported only three enzymes from a similar rat SMG preparation with optimum $\mathrm{pH}$ values of 8.0 to 9.3 and with molecular weights of 22,000 to $30,000 .^{6}$ Although fluorescein-labeled antibody to one of the six mouse esteropeptidases was localized over the convoluted tubules, 27 there is no evidence for intercellular localization of the rat SMG enzymes.

In the present study, the immunohistochemical reaction localized the antigenic protein from the $\mathrm{S}_{4}$ fraction to granules of the convoluted tubules. This finding as well as the single, arching precipitation line without spurs observed on immunodiffusion plates suggests that a major cytosol protein (Fig 3) was antigenically related to protein from each of the four column fractions and probably was derived from proteins solubilized from the granule contents. Electron microscopy confirmed that many granules were artifactually broken during the homogenization procedure.

Antibodies to proteins derived from the dense granules have not been localized to endoplasmic reticulum or to Golgi structures in the cells of the convoluted tubules by ultrastructural immunohistochemistry. How-

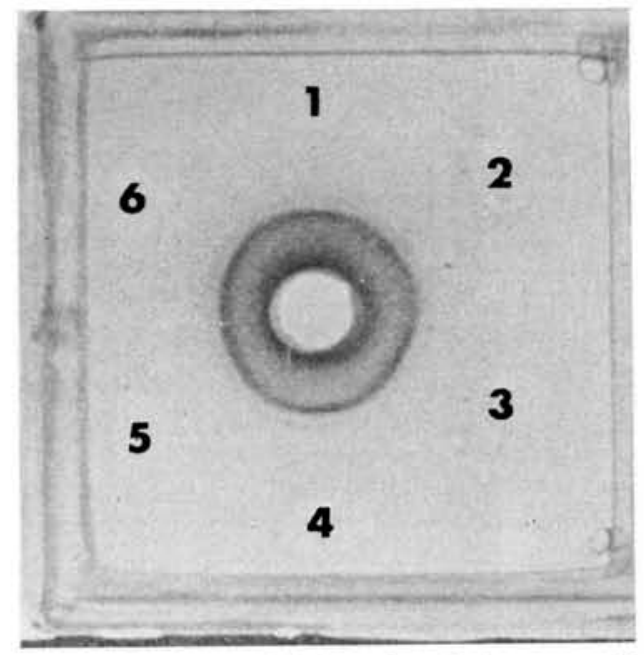

FIG 6.-Double diffusion in $1 \%$ agar gel. Center well contained $0.05 \mathrm{ml}$ undiluted purified antibody preparation; wells 1 and $4,0.05 \mathrm{ml}$ each of 1:32 dilution (optimal) of original antigen; wells 2, 3, 5, and 6, $0.05 \mathrm{ml}$ each, respectively, of undiluted fractions 22, 28, 31, and 33 from DEAE cellulose column (Fig 7). Single, continuous, and converging precipitation line at site of formation of insoluble antigen-antibody complexes. 


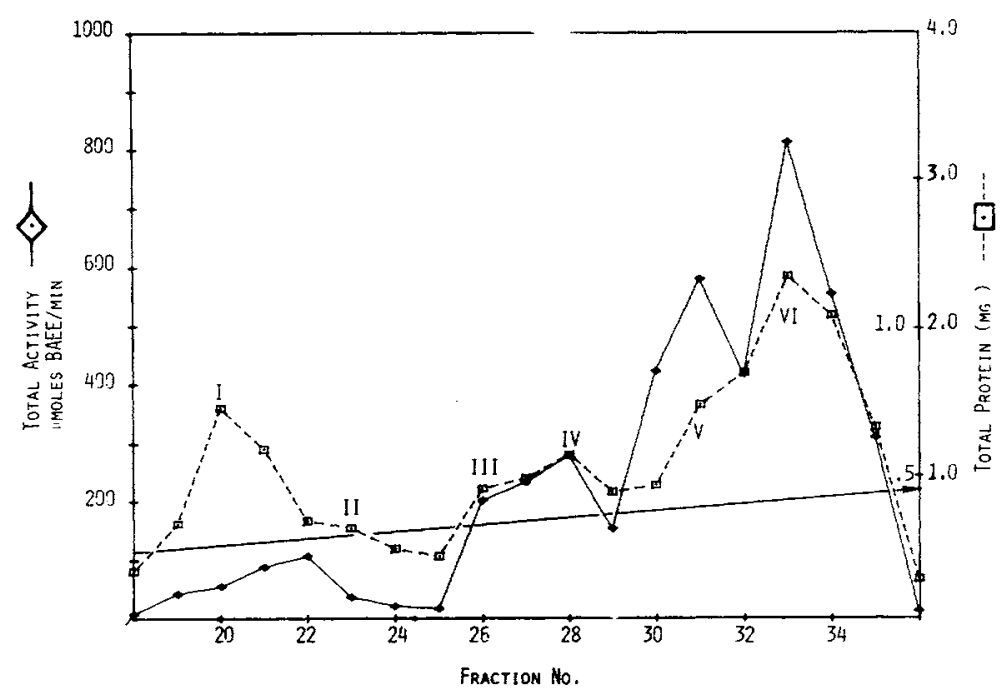

FIc 7.-Abscissa, column fraction number $(10 \mathrm{ml}$ each) from DEAE cellulose chromatography of pooled fractions 12 to 21 in Figure 1; left ordinate, total enzyme act per fraction expressed in $\mu$ moles BAEE hydrolyzed per minute; right outer ordinate, total milligrams of protein per fraction; right inner ordinate, molar concentration of $\mathrm{NaCl}$ eluting solution. Broken line, protein; solid line, alkaline esteropeptidase activity; arrow, $\mathrm{NaCl}$ elution gradient.

ever, detection of immunofluorescence associated with esteropeptidases and epidermal growth factor in mouse SMG tubules 27,28 as well as peroxidase reaction predominantly within the granules of the cells in the present study, strongly support the hypothesis that the enzymes are stored in secretory granules. Furthermore, it has been shown that the contents of the granules are discharged massively into the tubule lamina after pilocarpine administration. ${ }^{29}$ Subsequently, there is proliferation of endoplasmic reticulum and Golgi membranes. Eventually, condensing vacuoles and mature zymogen granules reform in the fully-recovered secretory cells. Under stimulated conditions, this structural recovery process takes at least eight hours, several hours longer than acinar cells of guinea pig pancreas after degranulation by refeeding of starved guinea pigs. ${ }^{30}$ The synthetic cycle of zymogen granules roughly corresponds to the cycle of protein synthesis that has been studied best by radioautography. ${ }^{31}$ The relatively long period of protein synthesis as well as the cyclical secretion pattern may help to explain why many of the cells have relatively little endoplasmic reticulum but at the same time possess a large number of granules.

Protein digestion is only one biologic activity associated with AEP activity in both rat and mouse SMG. Other activities implicated include: kallekrein and renin activity in rat gland 16,17 and mouse gland ${ }^{15}$ and factors that promote in vivo and in vitro growth of sensory and sympathetic nerve cells ${ }^{14,32}$ and enhanced epidermal growth in newborn mice and cultured embryonic epidermis and mammary epithelium. 14,33 These factors also seem to manifest AEP activity. For example, the purified $\gamma$ subunit of nerve growth factor (NGF) from mouse SMG was able to hydrolyze $180 \mu$ moles BAEE/mg protein/min. ${ }^{34}$ Also, a rat SMG granule preparation having kallekrein activity also had a specific esterase activity of $173 \mu$ moles $\mathrm{BAEE} / \mathrm{mg}$ protein $/ \mathrm{min}$. $^{16}$ Mouse SMG granules with both kallekrein and renin activity hydrolyzed $266 \mu$ moles BAEE/mg protein/ min. ${ }^{15}$ Furthermore, AEP activity has been associated with soluble protein factors from mouse SMG that are capable of promoting in vitro growth of thymic lymphocytes, ${ }^{35}$ rat hepatoma cells, ${ }^{36}$ neoplastic epithelial cells, ${ }^{37}$ 


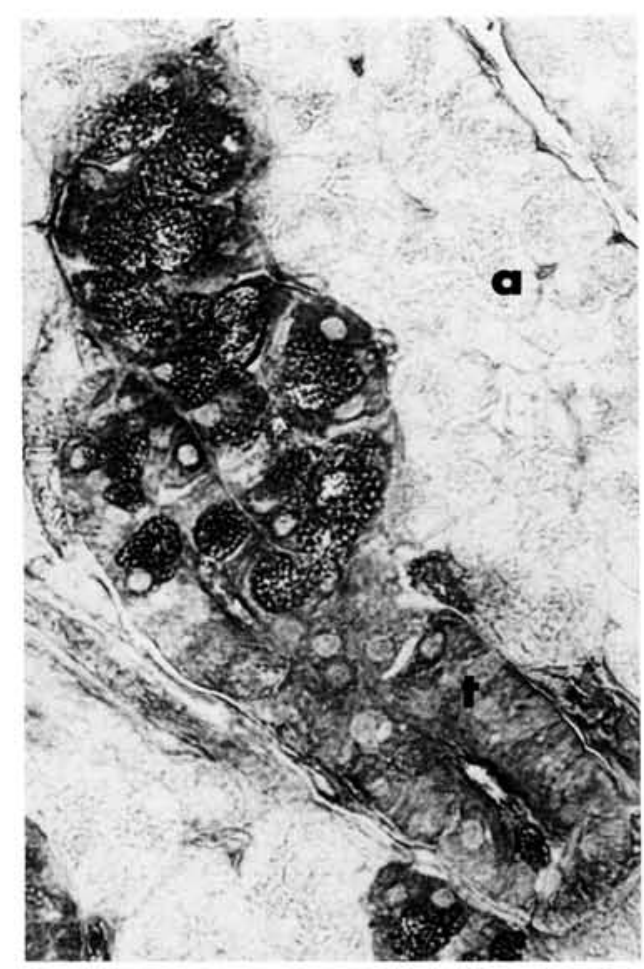

FIG 8.-Photomicrograph of peroxidase-labeled antibody reaction in rat SMG. Acinar cells (a) were unstained. Cytoplasm of duct and convoluted tubule ( $t$ ) cells without dense granules was light brown after reaction with DAB. Granules of convoluted tubules were stained dark brown to black indicating strong positive antigen-antibody reaction $(\mathrm{mag} \times 500)$.

and chick embryo skeletal muscle cells. ${ }^{4}$

In a study by Erdös, Tague, and Miwa, ${ }^{16}$ a major part of the BAEE esterase activity from rat SMG granules was attributed to kallekrein. However, the granule extracts were not purified further to resolve the number of proteins in the granules or the extent of their enzymatic or biologic activities. In the present study, polyacrylamide electrophoresis of four fractions eluted from a DEAE cellulose column resolved at least five different proteins. After treatment with SDS and $\beta$-mercaptoethanol, proteins from the same fractions exhibited variations in molecular weights of 6,500 to 55,000 daltons. However, we did not determine whether these proteins were biologically separate and discrete units and were disaggregated by the SDS treatment, or instead were derived by autolysis or dissociation of larger proteins into subunits.

The large 7S NGF protein complex with a molecular weight of 140,000 extracted from mouse SMG homogenate dissociates into three subunits of about $30,000 \mathrm{~mol}$ wt each either less than a $\mathrm{pH}$ of 5 or more than a $\mathrm{pH}$ of $8.38,39$ The large molecule of 140,000 mol wt and the subunit of $30,000 \mathrm{~mol}$ wt (that is, $\gamma$ subunit) have esteropeptidase activity as well as NGF activity. It has been suggested 14,39 that several of the other growth-promoting factors from mouse SMG such as mesenchymal growth factor, epidermal growth factor complex, thymotropic factor, and a fibroblast growth-promoting factor are either themselves esteropeptidases or are complexed with esteropeptidases. Additionally, they may share with trypsin and other proteases the ability to release cells from density-dependent inhibition by alteration of cell plasma membranes. This would suggest a biologic role for this kind of enzyme in promoting cell division in embryonic, neonatal, or regenerating tissue. In support of such a theory is the finding of EGF in mouse serum at the $1 \mathrm{ng} / \mathrm{ml}$ level and in normal mouse milk at the $200 \mathrm{ng} / \mathrm{ml}$ level by radioimmunoassay. ${ }^{33}$ This also sug. gests that the mouse EGF either is an endocrine secretory product of the SMG or is a separate product of the mammary gland and is simply cross-reactive with salivary EGF. There is other evidence for endocrine secretion by the rodent SMG. For example, NGF shares with proinsulin and insulin certain amino acid sequences in its structure and function. ${ }^{40}$ In addition, rat and mouse SMG have frequently been shown to contain renin activity. 15,17

To prove the hypothesis that promotion of cell growth in prenatal and postnatal animals is a major biologic function of these esteropeptidases, responsive tissues as well as mechanisms by which the proteins reach these tissues must be shown. A number of tissues responsive to these SMG factors have been demonstrated as previously discussed. Granules of the convoluted tubules are secreted into tubular lumina beginning around puberty, and alkaline esteropeptidases make up part of the zymogen secretory product. However, morphological evidence for the movement of granules from secretory cells to capillaries is lacking thus making the 
presence of various factors in serum difficult to interpret. A partial explanation may be found in evidence that several fibroblast cell lines (primary chick embryo, $\mathrm{L}_{2}, 3 \mathrm{~T} 3$ and SV-3T3 transformed cells) secrete proteins that mimic the biologic action of salivary NGF and are immunochemically cross-reactive with this factor. ${ }^{41}$ Thus, proteins from several body tissues may be structurally and functionally similar to the SMG factors and actually responsible for actions previously ascribed to these factors.

\section{Conclusions}

The granules of the convoluted tubules of the rat SMG contain a number of proteins with alkaline esteropeptidase activity which may at the same time be responsible for biologic activity simulating that of renin and kallekrein. In addition, they may be capable of promoting the growth of various cell populations as shown with factors found in mouse SMG. There is a contradiction then between the apparent zymogen nature of these granules, which are secreted into the saliva, and the endocrine nature of their biologic activity. This suggests that there may be more than one granule population in these tubules, that salivary enzymes are able to enter the blood stream by a yet undescribed pathway, or that there are structural and functional similarities between the salivary enzymes and factors secreted by other tissues.

There are still a large number of unanswered questions concerning the enzymes derived from rat SMG. What are the structural relationships between these enzymes and similar proteins in mouse SMG associated with renin, kallekrein, EGF, and NGF activity? If these biologic agents are indeed esteropeptidases, does specificity of biologic action reside in molecules on cell surfaces of responsible tissues or in the active sites in the enzyme structure or both? Evidence is accumulating also that NGF and other growth factors from mouse SMG may not act directly on neurons, but instead affect cells associated with the neurons, for example, mesenchymal cells, which in turn support the neurons by other mechanisms. 39,42 Thus, the mechanism of action as well as the method of transport of small polypeptide hormones to responsive tissues will be enhanced by further study of these salivary gland proteins.
The authors gratefully acknowledge the assistance of Mrs. H. Carr, Ms J. Pasich, Mrs. J. Seegert, and Mrs. H. Kassem.

\section{References}

1. Shackleford, J.M., and Klapper, C.E.: Casein Degrading Ability of Hamster, Rat and Mouse Salivary Glands, Arch Oral Biol 7: $337,1962$.

2. Attardi, D.G.; Levi-Montalcini, R.; WenGER, B.S.; and ANGELETTI, P.U.: Submaxillary Gland of Mouse: Effect of Fraction on Tissues of Mesodermal Origin In Vitro, Science 150: 1307, 1965.

3. ANGELETTI, R.A.; ANGeletti, P.U.; and CALISSANO, P.: Testosterone Induction of Esteroproteolytic Activity in the Mouse Submaxillary Gland, Biochim Biophys Acta 139: 372, 1972.

4. AtTARd, D.G.; Schlesinger, M.Z.; and SCHLESINGER, S.: Submaxillary Gland of Mouse:Properties of a Purified Protein Affecting Muscle Tissue In Vitro, Science 156: $1253,1967$.

5. Ekfors, T.O.; Riekkinen, P.J.; Malmiharju, T.; and Hopsu-Havu, V.K.: Four Isozymic Forms of a Peptidase Resembling Kallekrein Purified from the Rat Submandibular Gland, Hoppe-Seyler's $Z$ Physiol Chem 348: $111,1967$.

6. Hopsu-Havu, V.K.; RiekKineN, P.I:; and EkFors, T.O.: Studies on the Alkaline Trypsin-Like Enzymes in Rat Submandibular Gland and Saliva, Acta Odontol Scand 25: $657,1967$.

7. Riekkinen, P.J.; Ekfors, T.O.; and HorsuHAvU, V.K.: Purification and Characteristics of an Alkaline Protease from Rat Submandibular Gland, Biochim Biophys Acta 118: 604, 1966.

8. Minato, A.; Hirose, S.; and Hayashi, S.: Studies on Proteases in Submaxilliary Gland: I. Fractionation and General Characteristics of Rat Submaxillary Proteases, Chem Pharm Bull (Tokyo) 15: 1956, 1967.

9. RiekKinen, P.J.; EkFors, T.O.; Hollmen, T.; and Hopsu-Havu, V.K.: Purification and Physical Characieristics of a Trypsin-Like Protease from the Rat Submandibular Gland, Enzymology 32: 97, 1967.

10. RifkKinen, P.J.; EKFors, T.O.; and HopsuHavu, V.K.: Substrate Specificity and Modifier Characteristics of Alkaline Protease from the Rat Submandibular Gland:Glandulain, Enzymology 32: 110, 1967.

11. Galissano, P., and Angeletti, P.U.: Testosterone Effect on the Synthetic Rate of Two Esteropeptidases in the Mouse Submaxillary Gland, Biochim Biophys Acta 156: 51, 1968.

12. Schenkein, I.; Boesman, M.; Tokarsky, E.; Fishman, L.; and Levy, M.: Proteases from Mouse Submaxillary Gland, Biochem Biophys Res Commun 36: 156, 1969. 
13. Ekfors, T.O.; MalmiharJu, T.; and HopsuHavu, V.K.: Isolation of Six Trypsin-Like Esteropeptidases from the Mouse Submandibular Gland, Enzymology 43: 151, 1972.

14. Pasquini, F.; Petris, A.; Sbaraglia, G.; Scopelliti, R.; Cenci, G.; and Frati, L.: Biological Activities in the Granules Isolated from the Mouse Submaxillary Gland, Exp Cell Res 86: 233, 1974.

I5. Ghiang, T.S.; Erdös, E.G.; Miwa, I.; Tague, L.L.; and COALSON, J.J.: Isolation from a Salivary Gland of Granules Containing Renin and Kallekrein, Circ Res 23: 507, 1968.

16. ERDös, E.G.; TAGUE, L.L.; and MrwA, I.: Kallekrein in Granules of the Submaxillary Gland, Biochem Pharmacol 17:667, 1968.

17. Hackenthal, E.; Koch, C.; BergemanN, T.; and Gross, F.: Partial Purification and Characterization of a Renin-Like Enzyme from Rat Submandibular Gland, Biochem Pharmacol 21: 2779, 1972.

18. Hanks, C.T., and Chakrabarti, S.G.: Biochemical and Morphological Studies of Rat Submandibular Gland: I. Centrifugal Fractionation of Granule-Rich Fraction, $J$ Dent Res 54: 938-947, 1975.

19. Lowry, O.H.; Rosenbrough, N.J.; Fair, A.L.; and RANDALL, R.J.: Protein Measurement with the Folin Phenol Reagent, $J$ Biol Chem 193: 265, 1951.

20. KAPItANy, R.A., and Zebrowski, E.J.: High Resolution PAS Stain for Polyacrylamide Gel Electrophoresis, Anal Biochem 56:361, 1973.

21. Campbell, D.H.; Garvey, J.S.; CRemer, N.E.; and Sussborf, D.H.: Methods in Immunology, New York: W. A. Benjamin Publishers, 1964, pp 118-122.

22. Peterson, E.A., and Sober, H.A.: Chromatography of Proteins: I. Cellulose Ion-Exchange Adsorbents, $J A m$ Chem Soc 78: 751, 1956.

23. Nakane, P.K., and Pifrce, G.B.: EnzymeLabeled Antibodies: Preparation and Application for the Localization of Antigens, $J$ Histochem Cytochem 14: 929, 1967.

24. Stefanini, M.; Demartino, C.; and Zamboni, L.: Fixation of Ejaculated Spermatozoa for Electron Microscopy, Nature (Lond) 216: $173,1967$.

25. Nakane, P.K.: Personal communication.

26. Ekrors, T.O., and Hopsu-Havu, V.K.: Properties of the Esteropeptidases Purified from the Mouse Submandibular Gland, Enzymology 43: 177, 1972.

27. EKFors, T.O., and Hopsu-Havu, V.K.: Immunofluorescent Localization of TrypsinLike Esteropeptidases in the Mouse Submandibular Gland, Histochem J 3: 415, 1971.

28. Turkington, R.W.; Males, J.L.; and Cohen, S.: Synthesis and Storage of Epithelial-Epidermal Growth Factor in Submaxillary Gland, Cancer Res 31: 252, 1971.
29. Cutler, L.S., and Chaudhry, A.P.: Release and Restoration of the Secretory Granules in the Convoluted Granular Tubules of the Rat Submandibular Gland, Anat Rec 176: 405, 1973.

30. Palade, G.E.: Intracisternal Granules in the Exocrine Cells of the Pancreas, $J$ Biophys Biochem Cytol 2: 417, 1956.

31. Warshawsky, H.; Leblond, C.P.; and Droz, B.: Synthesis and Migration of Proteins in the Cells of the Exocrine Pancreas as Revealed by Specific Activity Determination from Radioautographs, $J$ Cell Biol 16: 1, 1963.

32. Levi-Montalcini, R.: Effects of Mouse Tumor Transplantation on the Nervous System, Ann NY Acad Sci 555: 330, 1952.

33. Cohen, S.: Epidermal Growth Factor, $J$ Invest Dermatol 59: 13, 1972.

34. Green, L.A.; Shooter, E.M.; and VARON, S.: Enzymatic Activities of Mouse Nerve Growth Factor and Its Subunits, Proc Natl Acad Sci, USA 60: 1983, 1968.

35. NaughtoN, M.A.; Koch, J.; HoffmaN, H.; Bender, V.; Hagopian, H.; and Hamilton, E.: Isolation and Activity of a ThymocyteTransforming Factor from the Mouse Submaxillary Gland, Exp Cell Res 57: 95, 1969.

36. Grossman, A.; Lele, K.P.; and Sheldon, J.: The Effect of Esteroproteases from Mouse Submaxillary Gland on the Growth of Rat Hepatoma Cells in Tissue Culture, Exp Cell Res 54: 260, 1969.

37. Jones, R.O., and Ashwood-Smrth, M.R.: Some Preliminary Observations on the Biochemical and Biological Properties of an Epithelial Growth Factor, Exp Cell Res 59: $161,1970$.

38. VAron, S.; NAmura, J.; and Shooter, E.M.: Reversible Dissociation of the Mouse Nerve Growth Factor Protein into Different Subunits, Biochem 7: 1296, 1968.

39. Greene, L.A.; Tomita, J.T.; and VAron, S.: Growth Stimulating Activities of Mouse Submaxillary Esteropeptidases on Chick Embryo Fibroblasts in Vitro, Exp Cell Res 64: $387,1971$.

40. Frazier, W.A.; ANgeletti, R.H.; and BradsHAw, R.A.: Nerve Growth Factor and Insulin, Science 176: 482, 1972.

41. YOUnG, M.; OGer, J.; BlanchaRD, M.H.; Asdourian, H.; Amos, H.; and Arnason, B.G.: Secretion of a Nerve Growth Factor by Primary Chick Fibroblast Cultures, Science 187: 361, 1975 .

42. Burnham, P.; Raiborn, G.; and Varon, S.: Replacement of Nerve-Growth Factor by Ganglionic Non-Neuronal Cells for the Survival in Vitro of Dissociated Ganglionic Neurons, Proc Natl Acad Sci, USA 69:3556, 1972. 